The Making of the Modern Body 



\section{The Making of the Modern Body}

Sexuality and Society

in the Nineteenth Century

EDITED BY

Catherine Gallagher and Thomas Laqueur

University of California Press

Berkeley · Los Angeles · London 
University of California Press

Berkeley and Los Angeles, California

University of California Press, Ltd.

London, England

(C) 1987 by

The Regents of the University of California

Originally published as REPRESENTATIONS, no. 14, Spring 1986

\section{Library of Congress Cataloging-in-Publication Data}

The Making of the modern body.

“Originally published as Representations, no. 14, Spring 1986"-T.p. verso.

1. Sex-Miscellanea. 2. Sex-History-19th

century. 3. Sex-Social aspects. I. Gallagher, Catherine.

II. Laqueur, Thomas Walter. III. Representations

(Berkeley, Calif.)

QP251.S4828 $1987 \quad 305.3 \quad 86-19361$

ISBN 0-520-05960-3 (alk. paper)

ISBN 0-520-05961-1 (pbk. : alk. paper)

Printed in the United States of America

$\begin{array}{lllllllll}12 & 3 & 4 & 5 & 6 & 7 & 8 & 9\end{array}$ 